UDK: 340.66

343.148:656.1.086.15

\title{
PREVALENCE OF POST-MORTEM BLOOD ALCOHOL CONCENTRATION AMONG DEATHS IN SERBIA DURING $2011^{1}$
}

\author{
Nada Bošnjaković Pavlović \\ Marijana Stefanović ${ }^{* * *}$ \\ Slobodan Anićc \\ Borivoj Adnađevićn ${ }^{* * * * *}$ \\ Faculty of Physical Chemistry, University of Belgrade \\ Mihajlo Jeličić \\ Vera Lukic ${ }^{* *}$ \\ Institute of Forensic Medicine, Belgrade \\ Snežana Uskoković Marković \\ Faculty of Pharmacy, University of Belgrade
}

\begin{abstract}
The prevalence of alcohol in blood samples from medicolegal autopsies performed in the Institute of Forensic Medicine in Belgrade, in 2011, was studied. In total, 293 blood samples were analyzed for alcohol by headspace gas chromatography. The blood alcohol concentrations were evaluated according to sex, age, and cause of death. The blood alcohol concentrations were ${ }^{3} 0.5 \mathrm{~g} / \mathrm{L}$ in $23.9 \%$ of the cases; in suicides $22.4 \%$, accidents $34.4 \%$ and homicides $25.0 \%$. The largest proportion of high BACs were found in the sample from subjects killed in traffic accidents. These findings confirm that alcohol use is an important factor in many fatal accidents, suicides and cases of violent death.
\end{abstract}

Keywords: forensic; post-mortem blood alcohol concentration; gas chromatography; traffic accidents; violent deaths.

1 This article is part of specialist work of Marijana Stefanovic on the Faculty of Physical Chemistry, University of Belgrade. The authors would like to thank the Institute of Forensic Medicine in Belgrade for their technical support and cooperation during the preparation of this article. The present investigations were partially supported by The Ministry of Education, Sciences, and Technological Development of Serbia, under Projects 172015 and 172043.

** Research Associate, nadab@ffh.bg.ac.rs

$* * *$ student, marijanastefanovicue@gmail.com

$* * * * \quad$ Associate Professor, boban@ffh.bg.ac.rs

$* * * * * \quad$ Full Professor, bora@ffh.bg.ac.rs

$* * * * * * \quad$ student, mjelicic@med.bg.ac.rs

$* * * * * * *$ specialist off toxicology, vera_lukic2006@yahoo.com

$\star \star * \star * * * *$ Assistant Professor, snezaum@pharmacy.bg.ac.rs 


\section{Introduction}

Alcohol is the most commonly toxic substance encountered in forensic toxicology for a simple reason that heavy drinking and drunkenness are contributing factors in many fatal accidents, trauma deaths, suicides, homicides, crimes of violence and antisocial behaviour in general. ${ }^{9}$ Its importance varies by cause of injury. Accordingly, alcohol is regularly analysed in blood samples from legal autopsies, and blood alcohol concentrations (BACs). ${ }^{10}$

The qualitative and quantitative determination of ethanol in various biological specimens (human whole blood, serum, urine, and faecal supernatants) has become a relatively simple analytical procedure giving accurate, precise and specific results. ${ }^{11}$ Head-space gas chromatography (HS-GC) has become the standard method for alcohol determination in forensic toxicology.

\section{Alcohol and fatalities}

Previously reported studies have investigated the prevalence and concentration of alcohol in medico-legal autopsies in relation to the cause of death and age. A high proportion (33-69\%) of positive blood alcohol concentrations has been found among suicide completers ${ }^{12}$ and studies have consistently confirmed this. Previous research has consistently identified and documented the presence of alcohol among homicide victims in varied settings. ${ }^{13}$ Alcohol intoxication among motor vehicle drivers increases the risk for involvement in a road traffic accident significantly. ${ }^{14}$ The Grand Rapid study ${ }^{15}$ in Michigan was the largest controlled study of alcohol related automobile collisions when it was conducted, and included 5,895 accident group and 7,590 control group drivers. Borkenstein and colleagues found that blood alcohol concentrations (BACs) above 0.04 were associated with an increased accidental rate and increasing exponentially at BACs of $0.08 / 0.10$ or greater. Similar findings were found in the Long Beach/Fort Lauderdale case control study. ${ }^{16} \mathrm{~A}$

9 F. C. Kugelberg; A. W. Jones, Interpreting results of ethanol analysis in post-mortem specimens: A review of the literature, For Sci Int, 165, 10-29, 2007.

10 B. S. De Martinis; M. C. De Paula; A. Braga; H. T. Moreira; C. S. Martin, Alcohol distribution in different postmortem body fluids, Hum Exp Toxicol, 25, 2006, 93-97.

11 F. Tagliaro; G. Lubli; S. Ghielmi; D. Franchi; M. Marigo, Chromatographic methods for blood alcohol determination, J. Chromatogr, 1992, 580, 161-190.

12 C. J. Cherpitel; G. L. Borges; H. C. Wilcox, Acute alcohol use and suicidal behavior: a review of the literature, Alcohol Clin Exp Res, 2004, 28, 18-28; S. M. R. Hufford, Alcohol and suicidal behaviour, Clin Psychol Rev, 2001, 21, 797-811.

13 J. B. Kuhns; D. B. Wilson; T. A. Clodfelter; E. R. Maguire; S. A. Ainsworth, A meta-analysis of alcohol toxicology study findings among homicide victims, Addiction, 106, 2011, 62-72.

14 G. F. McCoy; R. A. Johnstone; I. W. Nelson; R. B. Duthie, A review of fatal road accidents in Oxfordshire over a 2-year period. Injury, 20, 1989, 65-68. M. D. Robertson; O. H. Drummer; Responsibility analysis. A methodology to study the effects of drugs in driving. Accid Anal Prev 1994, 26, 243-247.

15 R. F. Borkenstein; R. F. Crowther; R. F. Shumate; W. B. Ziel; R. Zylman, The role of the drinking driver in traffic accidents (the Grand Rapids study). Blutalkohol, 1974, 11, 1-131

16 R. D. Blomberg; R. C. Peck; H. Moskowitz; M. Burns; D. Fiorentino, The Long Beach/Fort Lauderdale relative risk study, J Safety Res, 40, 2009, 285-292. 
relative risk function for drivers responsible for causing an accident, derived from epidemiological data collected in Grand Rapids was one basic argument for setting BAC limits in many countries. A BAC of $0.50 \mathrm{~g} / \mathrm{L}$, or even lower, ${ }^{17}$ may increase trauma severity and outcome of an injured patient. Research shows that the likelihood of road traffic crashes and injury is higher in young people than in older individuals at the same BAC levels. ${ }^{18}$ As a result, some countries impose a special BAC limit for young or less experienced drivers.

The aim of this study was to investigate the prevalence and concentrations of alcohol in blood samples from medico-legal autopsies that were conducted at the Institute of Forensic Medicine in Belgrade during 2011 and to present findings in relation to the type of death. ${ }^{19}$

\section{Materials and methods}

All cases that were autopsied at the Institute of Forensic Medicine in Belgrade during 2011 were included $(n=293)$. Approximately $80 \%$ of the cases were from the Belgrade area, the remaining were from other parts of Serbia. The cases were divided into natural deaths and non-natural violent deaths. Violent deaths were disaggregated into suicide, homicide, road traffic accident and unintentional death, such as freezing, or home accidents. The following variables were included in the study: age, gender, manner of death, specific cause of death. BAC was reported in $\mathrm{g} / \mathrm{L}$. A BAC of $0.5 \mathrm{~g} / \mathrm{L}$ was used as a main threshold value, and deceased persons with a BAC of $1.0 \mathrm{~g} / \mathrm{L}$ or higher were considered to have been intoxicated. Blood alcohol concentration ranged from 0.07 to $5.0 \mathrm{~g} / \mathrm{L}$. Blood samples were obtained from the femoral vein during the autopsy itself, which was performed 12-36 hours after the victim's death. Full blood samples were collected without preservatives into dry, glass headspace vial and hermetically sealed. The samples were stored at $-20^{\circ} \mathrm{C}$ prior to analysis.

\subsection{Preparation of standard}

A stock solution of ethanol (concentration $5.0 \mathrm{~g} / \mathrm{L}$ ) was diluted for preparing the set of ethanol standards in concentrations (in g/L) 0.156, 0.312, 0.625, 1.250, 2.500 and 5.000 -for use in constructing the calibration curve $(y=0.4982 \mathrm{x}-0.0055, \mathrm{r}=$ 0.99997). The limit of ethanol detection was set at $0.01 \mathrm{~g} / \mathrm{L}$ and the limit of ethanol quantification was $0.03 \mathrm{~g} / \mathrm{L}$. $n$-Propanol was used as the internal standard.

17 P. Howat; D. Sleet; I. Smith, Alcohol and driving: is the $0.05 \%$ blood alcohol concentration limit justified? Drug Alcohol Rev, 1991, 10, 151-166.

18 World Health Organization (WHO) 2013. Global status report on road safety. 2013: supporting a decade of action

19 The ethics Committee of the University of Belgrade - School of Medicine approved the use of results reported in this work. 


\subsection{Sample preparation}

Preparation of the blood samples for analysis was carried out by measuring 0.1 $\mathrm{mL}$ of full blood in the glass headspace vial, by adding $0.50 \mathrm{~g} \mathrm{NaCl}$ and $0.1 \mathrm{~mL} 1 \mathrm{~g} / \mathrm{L}$ solution of $n$-propanol. Vials containing blood samples were heated at $60^{\circ} \mathrm{C}$ for 20 minutes in a Hewlett Packard headspace sampler 19395 A (Agilent technologies, Santa Clara CA, USA), before analysed.

\subsection{Analytical instrument settings}

A Hewlett Packard 5890 series II gas chromatograph (Agilent Technologies) with a flame ionization detector was used. The analytical column was a Permabond CW20M (Agilent Technologies) $-0.3525 \mu \mathrm{m} \times 0.32 \mathrm{~mm}$ i.d., $\mathrm{t}=40^{\circ} \mathrm{C}$. The temperature of the FID was $250^{\circ} \mathrm{C}$, and the injector temperature was $200^{\circ} \mathrm{C}$. The method was validated. The accuracy was determined as percent recovery of spiked samples and ranged between 95.4 and 109.4\%. System precision was established by measuring the response of six replicate injections of the standard solution. The RSD values of $0.79 \%$ indicate that the method has an acceptable level of precision $(\mathrm{RSD} \leq 1 \%)$.

\section{Results}

The blood samples of 293 post-mortem cases were investigated. Among them, 191 cases $(65.2 \%)$ had no alcohol in the blood, while in 102 cases $(34.8 \%)$ the blood alcohol concentration was between 0.07 to $5.00 \mathrm{~g} / \mathrm{L}$ (Table 1). It was found that $180 / 293(61.4 \%)$ and $113 / 293$ (38.5\%) fatalities were violent and natural deaths, respectively. Among the violent deaths we found that $67 / 180$ (37.2\%) were suicides, $12 / 180(6.6 \%)$ were homicide and 96/180 (54.8\%) were from road traffic accidents. Tweenty eight cases out of 102 were identified as alcohol-influenced natural deaths, representing 27.4\%. Half of these were recoreded with BAC higher than $1.00 \mathrm{~g} / \mathrm{L}$.

Table 1 - Number and percent of subjects for different manners of death

\begin{tabular}{|c|c|c|c|c|}
\hline Manner of death & $\begin{array}{l}\text { Men } \\
\text { Total/pos. alc. }\end{array}$ & $\begin{array}{l}\text { Women } \\
\text { Total/pos. alc. }\end{array}$ & $\begin{array}{l}\text { Number } \\
\text { Total/pos. alc. }\end{array}$ & $\begin{array}{l}\text { \% } \\
\text { Total/pos. alc. }\end{array}$ \\
\hline Homicide & $8 / 4$ & $4 / 1$ & $12 / 5$ & $4.1 / 4.9$ \\
\hline Suicide & $51 / 19$ & $16 / 3$ & $67 / 22$ & $22.9 / 21.6$ \\
\hline Road traffic accidents & $81 / 40$ & $15 / 2$ & $96 / 42$ & $32.8 / 41.2$ \\
\hline Natural death & $76 / 26$ & $37 / 2$ & $113 / 28$ & $38.6 / 27.5$ \\
\hline Unintentional death & $4 / 4$ & $1 / 1$ & $5 / 5$ & $1.7 / 4.9$ \\
\hline Total & $220 / 93$ & $73 / 9$ & $293 / 102$ & $100 / 100$ \\
\hline
\end{tabular}

Table 2. shows the BAC concentrations of the 102 decedents that tested positive for alchohol by manner of death. The determined post-mortem BAC varied by 
injury mechanism. Of all deaths involving alcohol, $68.6 \%(71 / 102)$ had over 0.50 $\mathrm{g} / \mathrm{L}$. The greatest proportion of alcohol related deaths belonged to a BAC range between 2.00 and $2.99 \mathrm{~g} / \mathrm{L}$. Ten cases had levels $\geq 3.00 \mathrm{~g} / \mathrm{L}$, which some studies regard as being lethal. Five of them were traffic accidents. The highest blood alcohol concentration was $4.8 \mathrm{~g} / \mathrm{L}$. For 32 cases of death, the BAC concentration was $<0.50$ $\mathrm{g} / \mathrm{L}$. It was interesting to notice that among these cases, natural deaths comprised 13 out of 32 cases. In 50 cases of death, the BAC was $1.00-2.99 \mathrm{~g} / \mathrm{L}$. It is interesting that 22/50 were road traffic accidents and 13/50 were suicides. In cases of suicide, $32.8 \%$ ( 22 of all 67 ) had a positive BAC. In 8 cases, the BAC was less than $1.00 \mathrm{~g} / \mathrm{L}$, and in 14 cases, it was $>1.00 \mathrm{~g} / \mathrm{L}$. Alcohol was found in $41.6 \%$ of homicide victims.

Table 2 - Distribution of blood alcohol concentrations for different manners of death

\begin{tabular}{|ll|l|l|l|l|l|l|}
\hline \multirow{2}{*}{ Manner of death } & \multicolumn{2}{c}{} & \multicolumn{6}{c|}{ BAC (g/L) } \\
\cline { 2 - 10 } & Number & $\mathbf{0}$ & $<\mathbf{0 . 5 0}$ & $\mathbf{0 . 5 0 - 0 . 9 9}$ & $\mathbf{1 . 0 0 - 1 . 9 9}$ & $\mathbf{2 . 0 0 - 2 . 9 9}$ & $\geq \mathbf{3 . 0 0}$ \\
\hline Homicide & 5 & 4.9 & 2 & 2 & 0 & 0 & 1 \\
\hline Suicide & 22 & 21.6 & 7 & 1 & 4 & 9 & 1 \\
\hline Road traffic accidents & 42 & 41.1 & 9 & 6 & 11 & 11 & 5 \\
\hline Natural death & 28 & 27.4 & 13 & 1 & 6 & 6 & 2 \\
\hline Unintentional death & 5 & 4.9 & 1 & 0 & 1 & 2 & 1 \\
\hline Total & 102 & 100 & 32 & 10 & 22 & 28 & 10 \\
\hline
\end{tabular}

\subsection{Road traffic accidents}

In the cases of road traffic accidents, in a total of 96 cases, positive blood alcohol concentation was found in $42(43.8 \%)$ cases (Table 1$)$. Blood alcohol concentration exceeding $0.50 \mathrm{~g} / \mathrm{L}$ was found in $34.4 \%$ (33 cases) of all drivers (Table 2). Male victims accounted for $84.4 \%$ of fatalities, while females constituted $15.6 \%$. The blood alcohol range for traffic accident victims was $1.00-2.99 \mathrm{~g} / \mathrm{L}$ in $22.9 \%$.

Men of 35 to 45 years of age had higher BAC levels than older men (Table 3). It is interesting to note that five cases had BAC higher than $3.00 \mathrm{~g} / \mathrm{L}$.

\subsection{Age}

Table 3 presents mean ages of deaths for different BAC intervals. A statistically significant difference was found between the mean age of the BA positive deceasents, 45.0 years (BAC is higher than $0.50 \mathrm{~g} / \mathrm{L}$ ) and those negative for $\mathrm{BA}$ at the time of death (60.9 years). 
Nada Bošnjaković Pavlović, Marijana Stefanović, Slobodan Anić, Borivoj Adnađević, Mihajlo Jeličić, Vera Lukić, Snežana Uskoković Marković

Table 3 - Mean age of death in relation to blood alcohol concentration (number of cases in brackets)

\begin{tabular}{|c|c|c|c|c|c|c|c|}
\hline $\begin{array}{l}\text { Manner of death } \\
\mathrm{BAC}(\mathrm{mg} / \mathrm{mL})\end{array}$ & & Homicide & Suicide & $\begin{array}{l}\text { Road } \\
\text { traffic } \\
\text { accidents }\end{array}$ & $\begin{array}{l}\text { Natural } \\
\text { death }\end{array}$ & $\begin{array}{l}\text { Unintentional } \\
\text { death }\end{array}$ & Total \\
\hline none & Average age & $50.3(7)$ & $59.6(45)$ & $48.5(54)$ & $68.1(85)$ & $0(0)$ & $60.9(191)$ \\
\hline$<0,50$ & Average age & $67.5(2)$ & $53.7(7)$ & $49.9(9)$ & 63.013) & $60(1)$ & $58.9(32)$ \\
\hline $0,50-0.99$ & Average age & $34.5(2)$ & $73.0(1)$ & $30.7(6)$ & $64.0(1)$ & $0(0)$ & $39.0(10)$ \\
\hline $1.00-1.99$ & Average age & & $50.3(4)$ & $38.1(11)$ & $44.0(6)$ & $49(1)$ & $45.0(22)$ \\
\hline $2.00-2.99$ & Average age & & $50.2(9)$ & $45.7(11)$ & $49.0(6)$ & $63(1)$ & $51.0(27)$ \\
\hline$\geq 3.0$ & Average age & $55.0(1)$ & $43.0(1)$ & $44.8(5)$ & $56.0(2)$ & $57(2)$ & $46.9(11)$ \\
\hline Total av erage age & & 50.9 & 57.1 & 45.8 & 65.4 & 57 & 56.6 \\
\hline Total number & & 12 & 67 & 96 & 113 & 5 & 293 \\
\hline
\end{tabular}

Furthermore, when comparing mean ages between causes of death for the positive and negative groups, victims of violent deaths involving alcohol were younger for most causes of death (Table 3 ). The youngest victims were killed in road traffic accidents. The suicide victims were on average about 10 years older at the moment of death than accident victims. For all types of death, those with BACs between 0.50 and $1.00 \mathrm{~g} / \mathrm{L}$ had the lowest average age.

\subsection{Acute alcohol influence}

The best estimates of those fatalities in which alcohol is major contributing factors are represented by the percentages of intoxication in Table 4 . These percentages were $8.3 \%$ overall for homicide cases, $28.1 \%$ for road traffic accidents deaths, and $20.9 \%$ for suicide cases and $12.4 \%$ for natural death.

According to the reported results, $59.5 \%$ and $50.0 \%$ of the positive tested violent and natural deaths, respectively, had BAC higher than $1.00 \mathrm{~g} / \mathrm{L}$. For the total of 60 cases with BAC $\square 1.00 \mathrm{~g} / \mathrm{L}, 27$ cases were road traffic accidents and 14 were suicides. There were ten cases with BAC higher than $3.00 \mathrm{~g} / \mathrm{L}$. Five of ten cases were road traffic accidents. As revealed in Table 3, acute alcohol influence was considered as a contributory cause of death in road traffic accidents.

\subsection{Gender}

Males were more likely to have consumed any alcohol (75.0\%) than females (25.0\%). Men aged 35 to 45 years had the highest proportion of intoxication. About 93.3\% in all deaths with BAC higher than $1.00 \mathrm{~g} / \mathrm{L}$ were men (Table 4). 
Table 4 - Number and percentage of subjects intoxicated by alcohol (BAC $\geq 1.00 \mathrm{~g} / \mathrm{L})$ by gender and cause of death

\begin{tabular}{|ll|l|l|l|}
\hline \multirow{5}{*}{ Manner of death } & \multicolumn{5}{l}{ BAC $\geq \mathbf{1 . 0 0}(\mathrm{g} / \mathrm{L})$} & Total number & Prevalence (\%) \\
\cline { 2 - 6 } & Men & Women & 1 & 8.3 \\
\hline Homicide & 1 & 0 & 14 & 20.9 \\
\hline Suicide & 12 & 2 & 27 & 28.1 \\
\hline Road traffic accidents & 26 & 1 & 14 & 12.4 \\
\hline Natural death & 14 & 0 & 4 & 80.0 \\
\hline Unintentional death & 3 & 1 & 60 & 20.5 \\
\hline Total & 56 & 4 & & \\
\hline
\end{tabular}

\section{Discussion}

In this analysis we have presented the characteristics of acute alcohol influence in a series of medico-legally autopsied deaths, and the degree of acute alcohol influence relevant on the causes of death. Alcohol exerts a series of effects on the central nervous systems. These effects comprise general influence and intoxication affecting, for instance, judgement, and leading to impairment of various skills. Alcohol substantially increases the risk of an individual to die an unnatural and violent death as it blurs rational thinking and increases self-destructive behaviour and agressiveness toward others. It is debatable what $\mathrm{BAC}$ is necessary before acute alcohol influence should be regarded as a contributory cause of death. Factors such as size, time of last meal and alcohol tolerance all play a role in how alcohol impairs a person's coordination, vision and thinking. All such effects are generally more pronounced if the $\mathrm{BAC}$ is higher. A BAC of $0.50 \mathrm{~g} / \mathrm{L}$ is probably an appropriate threshold value in most cases of violent death. However, it cannot be excluded that the presence of blood alcohol in some cases is an incidental finding not related to the events leading to death. A BAC $\square 1.00 \mathrm{~g} / \mathrm{L}$ was in this study used to define acute alcohol influence as a contributory cause. Acute alcohol influence should be classifield as a contributory cause of death if the possibility exists that this influence contributed to death. ${ }^{20}$

However, interpreting post-mortem BAC results and drawing correct conclusions about ante-mortem levels and the person's state of inebriation and degree of behavioural impairment at the time of death can be complicated by various post mortem artifacts. ${ }^{21}$ The condition of the body, the time between death and autopsy, the environmental conditions (temperature and humidity) and the nature of the

20 I. Nordrum; T. J. Eide; L. Jorgensen; Alcohol in a series of medico-legal autopsied death in northern Norway. Forensic Sci Int, 110, 2000, 127-137.

21 H. Kalant, Interpretation of post-mortem ethanol concentrations. Aeros Med 1968, 39, 633637; Skopp, G. Postmortem toxicology, Forensic Sci Med Pathol, 6, 2010, 314-325. 
specimen collected for analysis are important factors to consider. Many species of bacteria, yeast, and moulds are capable of producing ethanol from a variety of substrates. The probability of post-mortem ethanol synthesis increases as storage temperature and the interval between death and autopsy increases. But, with careful consideration of all the information available, a valid interpretation of the source of ethanol, whether it be from ante-mortem ingestion or post-mortem production, can be made. Therefore, care should be taken when assessing BAC concentrations in fatal accidents involving severe trauma to the body or in cases where long delays occurred prior to the collection of specimens for toxicological analysis.

In the present materials, the prevalence of alcohol intoxication in victims was also notably high. $62.0 \%$ and $50.0 \%$ of those testing positive in violent and natural deaths, respectively, had BAC higher than $1.00 \mathrm{~g} / \mathrm{L}$. This shows that alcohol is a risk factor in injury event. During 2011, about half of the victims of homicides in Serbia were under the influence of alcohol at the time of their death. Our results are basically in accordance with previously published results from studies in other countries.22

In this paper, twenty eight cases out of 113 total natural deaths were identified as alcohol-influenced natural deaths, representing $24.7 \%$. Seven to $30 \%$ of natural deaths have been reported to have positive BAC. For the violent deaths, a BAC of 0.50 is an appropriate treshold value. However, what an appropriate treshold should be among natural deaths is more difficult to decide.

The present article shows that there are significant differences between females and males in alcohol-related fatalities due to external causes. According to the data, more male victims (about 90.0\%) than females had BACs that indicated binge drinking, suggesting that women in Serbia are less likely to be identified as drinkers. But, the presence of females in this analysis though few cases, showed that alcohol consumption is not limited to males only. Similar gender differences in alcohol drinking patterns were observed in other countries. ${ }^{23}$ As noted above, a significant difference was found between the mean age of the decedents with BAC higher than $0.50 \mathrm{~g} / \mathrm{L}$ and those with lower BACs. It is well established that the risk of accident is greatly increased among drivers who test positive for alcohol. In the last 20 years, many studies have examined the increased risk to the driving population while driving under the influence of alcohol. Even if studies report different $\mathrm{BAC}$ categories, we used the BACs of $1.00 \mathrm{~g} / \mathrm{L}$ or higher, because this is the most commonly accepted level indicating intoxication that has been widely used in other studies. This is the level at which the relative risk for motor vehicle crashes increases exponentially. ${ }^{24}$ In general, the highest BAC levels are probably more seriously considered as contributory cause than the lower ones. In our investigation, positive blood alcohol concentation was found in 42 cases (43.8\%) and 26 cases from 42,

22 G. S. Smith; C. C. Branas; T. R. Miller, Fatal non-traffic injuries involving alcohol: A metaanalysis, Ann Emerg Med, 1999, 33, 659-668.

23 M. Bellis; M. A. Bolster; C. T. Doyle, The role of alcohol in deaths presenting to the coroners service in Cork city and County, Ir Med J 2009, 102, 13-15. H. Sjogren; P. Valverius; A. Eriksson, Gender differences in role of alcohol in fatal injury events, Eur J Public Health, 2006, 16, 266-270.

24 D. I. Smith, Effect on traffic safety of introducing a $0.05 \%$ blood alcohol level in Queensland, Australia, Med Sci Law, 1988, 28, 165-167. 
the concentartion of BAC is higher that $2.00 \mathrm{~g} / \mathrm{L}$. This high prevalence of alcohol in our research is in line with previous research performed in other countries. The reported prevalence of alcohol in drivers in a recently reported systematic review from different countries shows that prevalence of alcohol is within the range 20$50 \%$. A study conducted in four European countries, ${ }^{25}$ Portugal, Finland, Sweden and Norway, showed that about $42 \%$ of the drivers were found positive for alcohol. The highest prevalence of alcohol was recorded in Portugal (44.9\%) and lowest in Sweden (19.0\%). This percentage was significantly higher than in the other countries. But, in Finland and Norway, the prevalence of drivers with a BAC above $1.30 \mathrm{~g} / \mathrm{L}$ was even higher $(71-8 \%)$.

It is not at all clear what role alcohol plays in suicides; it could be irrelevant; be used after the decision to take one's life has been made; or its use could be part of the set of conditions that lead to the decision to commit suicide. Several studies have documented a high proportion of suicide cases positive for blood alcohol. James $(1966)^{26}$ in a study of suicides in Western Australia in years 1961 to 1982 showed that $30 \%$ had positive blood alcohol concentration. Varadaraj and Mendonca $(1987)^{27}$ found in a study of 58 cases that $41 \%$ had consumed alcohol and $29 \%$ had a $\mathrm{BAC}$ greater than 0.80 . Since alcohol consumption is associated with the increase in the number of suicides, the present investigation consists of an analysis of BACs in victims of suicide autopsied in Serbia, in the year of 2011. According to the present study, positive results for alcohol were higher in male victims, and the mean $\mathrm{BAC}$ was higher in men, a finding similar to that of Varadaraj and Mendonca and other publications. About a third of victims of suicides were found to have positive BAC, but every fifth victim has very high BAC between 1.00-5.00 g/L. Generally, the results from this examination have produced similar findings to those from earlier studies that high rates of positive blood alcohol concentrations have been found among suicide completers.

Finally, the findings of this investigation strongly support the role of alcohol in accidental and violent deaths in Serbia. As a matter of fact, approximately every third of the victims analyzed were under the influence of alcohol at the moment of their death. The data presented in this article contribute to the understanding of the part alcohol intoxication plays in violence in the context of a developing society. The present paper suggests an important link between the alcohol intoxication and natural and violent death.

\section{Conclusion}

One out of three investigated deaths were associated with alcohol. Alcohol-associated mortality varied considerably between different causes of death, between men and women, and between age groups. Acute alcohol influence was considered as a contributory cause of death in many road traffic accidents.

25 S. A. Legrand; H. Gjerde; C. Isalberti; T. Van der Linden; P. Lillsunde; M. J. Dias et al. Prevalence of alcohol, illicit drugs and psychoactive medicines in killed drivers in four European countries, Int J Inj Contr Saf Promot, 2013 (Epub 9. Jan.).

26 P. James, Blood alcohol levels following successful suicide, QJ Stud Alcohol, 1966, 27, 23-29.

27 R. Varadaraj; J. A. Mendonca, Survey of blood alcohol levels in self-poisoning cases, $A d v$ Alcohol Subst Abuse 1987, 7, 63-69. 


\section{References}

1. Bellis, M; Bolster, M. A; Doyle, C. T; The role of alcohol in deaths presenting to the coroners service in Cork city and County, Ir Med J, 102, 2009.

2. Blomberg, R. D; Peck, R. C; Moskowitz, H; Burns, M; Fiorentino, D; The Long Beach/Fort Lauderdale relative risk study, J Safety Res, 40, 2009.

3. Borkenstein, R. F; Crowther, R. F; Shumate, R. F; Ziel, W. B; Zylman, R; The role of the drinking driver in traffic accidents (the Grand Rapids study). Blutalkohol, $11,1974$.

4. Cherpitel, C. J; Borges, G. L; Wilcox, H. C; Acute alcohol use and suicidal behavior: a review of the literature, Alcohol Clin Exp Res, 28, 2004.

5. De Martinis, B. S; De Paula, M. C; Braga, A; Moreira, H. T; Martin, C. S; Alcohol distribution in different postmortem body fluids. Hum Exp Toxicol, 25, 2006.

6. Howat, P; Sleet, D; Smith, I; Alcohol and driving: is the $0.05 \%$ blood alcohol concentration limit justified? Drug Alcohol Rev, 10, 1991.

7. Hufford, M. R; Alcohol and suicidal behavior, Clin Psychol Rev, 21, 2001.

8. James, P; Blood alcohol levels following successful suicide, Q J Stud Alcohol , 27, 1966.

9. Kalant, H; Interpretation of post-mortem ethanol concentrations, Aeros Med, 39, 1968.

10. Kugelberg, F. C; Jones, A. W; Interpreting results of ethanol analysis in postmortem specimens: A review of the literature, For Sci Int, 165, 2007.

11. Kuhns, J. B; Wilson, D. B; Clodfelter, T. A; Maguire, E. R., Ainsworth, S. A; A meta-analysis of alcohol toxicology study findings among homicide victims, Addiction, 106, 2011.

12. Legrand, S. A; Gjerde, H; Isalberti C; Van der Linden, T; Lillsunde, P; Dias, M. J. et al. Prevalence of alcohol, illicit drugs and psychoactive medicines in killed drivers in four European countries. Int J Inj Contr Saf Promot, 2013 (Epub 9. Jan.).

13. McCoy, G. F; Johnstone, R. A; Nelson, I. W; Duthie, R. B; A review of fatal road accidents in Oxfordshire over a 2-year period, Injury, 20, 1989.

14. Nordrum, I; Eide, T. J; Jorgensen, L; Alcohol in a series of medico legal autopsied death in northern Norway, Forensic Sci Int, 110, 2000.

15. Robertson, M. D; Drummer, O. H; Responsibility analysis. a methodology to study the effects of drugs in driving, Accid Anal Prev, 26, 1994.

16. Skopp, G; Postmortem toxicology, Forensic Sci Med Pathol, 6, 2010.

17. Sjogren, H; Valverius, P; Eriksson, A; Gender differences in role of alcohol in fatal injury events. Eur J Public Health, 16, 2006.

18. Smith, D. I; Effect on traffic safety of introducting a $0.05 \%$ blood alcohol level in Queensland, Australia, Med Sci Law, 28, 1988.

19. Smith, G. S; Branas, C. C; Miller, T. R; Fatal nontraffic injuries involving alcohol: A metaanalysis, Ann Emerg Med, 33, 1999.

20. Tagliaro, F; Lubli, G; Ghielmi, S; Franchi, D; Marigo, M; Chromatographic methods for blood alcohol determination, J Chromatogr, 580, 1992. 
21. Varadaraj, R; Mendonca, J. A; survey of blood alcohol levels in self-poisoning cases, Adv Alcohol Subst Abuse, 7, 1987.

\title{
REZULTATI POST MORTEM ANALIZE KONCENTRACIJE ALKOHOLA U KRVI U SRBIJI TOKOM 2011 GODINE
}

\author{
Nada Bošnjaković Pavlović \\ Marijana Stefanović \\ Slobodan Anić \\ Borivoj Adnađević \\ Fakultet fizičke hemije Univerziteta u Beogradu \\ Mihajlo Jeličić \\ Vera Lukić \\ Institut forenzičke medicine, Beograd \\ Snežana Uskoković Marković \\ Farmaceutski fakultet Univerziteta u Beogradu
}

\begin{abstract}
Rezime: U ovom radu su razmatrani rezultati post mortem koncentracije alkohola (BAC) u 293 uzorka krvi dobijena na osnovu sudsko-medicinskih autopsija sprovedenih na Instututu za sudsku medicinu u Beogradu tokom 2011. godine. Gasna hromatografija sa headspace tehnikom (HS GH) se koristi kao rutinska i referentna metoda za određivanje alkohola. Podaci su analizirani prema godištu i polu žrtve u trenutku smrti i prema uzroku smrti. Od ukupnog broja žrtava, svaka treća žrtva je bila pod uticajem alkohola u momentu smrti. BAC je bila $-0.5 \mathrm{~g} / \mathrm{L}$ u $23.9 \%$ slučajeva, i to $22.4 \%$ kod samoubistava, $34.4 \%$ kod nesrećnih slučajeva i $25.0 \%$ u slučajevima ubistava. Najveći procenat visokih vrednosti BAC utvrđen je u uzorcima subjekata nastradalih u saobraćajnim nesrećama. Kod žrtava saobraćajnih nesreća, od 42 slučaja pozitivnih na alkohol, 26 žrtava ima koncentracija alkohola u krvi veću od 2 g/L. 90\% žrtava pozitivno testiranih na alkohola su muškarci.Analiza pokazuje da je alkohol visok faktor rizika kod mnogih fatalnih nesreća, samoubistava i slučajeva nasilne smrti. Podaci izneti u ovom radu svakako bi trebalo da pomognu u razumevanju uloge alkohola u momentu smrti ali i da skrenu pažnju celom društvu u borbi protiv alkoholizma.
\end{abstract}

